\title{
Board Composition, Board Size and Market Value of Listed Industrial Goods Companies in Nigeria
}

\author{
Habib Abdulkarim, Abubakar Yusuf, Usman Isah \\ Department of Accounting, Gombe State University, Gombe - Nigeria
}

\begin{abstract}
This study examines the impact of board composition and board size on the market value of listed industrial goods companies in Nigeria. Ex-post factor research design was used and data was collected from annual reports and account of the sampled companies for the period from 2010 to 2019 . The ordinary least square, fixed and random effects regression techniques were applied on the panel data collated to estimate the models. The paper documents significant positive effect of board size on the market value of the companies and insignificant but negative effect of board composition on the market value of the companies. In effect, the result suggests that board size plays important role in determining the market value of the firms. These findings are consistent with the agency theory of corporate governance which suggests higher number of members on board. It is recommended that the size of the board of firms in the sector should not be less than 9 members so as to enhance value.
\end{abstract}

Keywords: Board Composition, Board Size, Market Value

\section{INTRODUCTION}

$\mathrm{T}$ he agency theory recognizes the role of monitoring mechanism with a view to reduce agency costs and avoid conflict of interests between managers and shareholders. Corporate board is the highest executive body of a company. It is therefore, responsible for the monitoring of the strategic affairs of the corporation on behalf of the shareholders, who elected them and to whom they are accountable. The Board must also be totally committed to administer the policies and procedures with openness, integrity, honesty and accountability. The board is also involve in pursuing the true spirit of Corporate Governance (CG), commensurate with the company's needs. However, for the board to be effective in discharging its duties and responsibilities, the size as well as its composition must be taken into consideration. Mousa and Al Manaser (2012) stated that the size and composition of the board play a pivotal role towards the achievement of the mandate of the board. Board size of an organisation is all about the number of directors both the executive and the nonexecutive sitting on the board, while the composition on the hand, is the proportion of non-executive directors (independent) to the total number of directors in an organisation (Adekunle \& Aghedo, 2014)

A company's market value is a good indication of investors' perceptions of its business prospects. The relationship between corporate board and firm market value is an essential area to focus on, as better governed firms could be more profitable because investors could expect higher future profit which could translate into more dividend on their investment and this could motivate them to invest more and even attract potential investors. Hamidu and Salihu (2015) stated that Market value is determined by the valuations accorded by investors to companies, such as price-to-sales, price-toearnings, enterprise value-to-Earnings Before Interests and Tax (EBIT), and so on. The higher the valuations, the greater the market value of the firm.

Furthermore, market value of a firm fluctuates over periods of time as a result of influenced by the business cycle and other factors, like the sector in which a company operates. Market values plunge during the periods that accompany recessions, and rise during the periods accompanying economic expansion. Market value is also dependent on numerous factors, such as the manner in which the company is being governed; that is the corporate governance put in place in the company's structure, the sector in which the company operates, its profitability, its debt load and the broad market environment (Omura, 2005). Because of the aforementioned factors and many others, motivate the selection of Nigerian industry goods sector for this study. In view of the above, the main aim of this study is to examine the relationship among board composition, board size and market value of industrial goods companies in Nigeria for the period of ten years from 2010 to 2019, by relating board composition with market value as well as board size with market value. In effect, the study raised the following questions:

i. How does board composition impact on market value of listed industrial goods companies in Nigeria?

ii. What impact do board sizes have on market value of listed industrial goods companies in Nigeria?

The remainder of the paper is organized as follows: Section two (2) provides literature review on board composition, board size and firm value. Section three (3) presents methodology of the study. Section four (4) presents results and discussions and lastly, section five (5) discusses conclusions and recommendations.

\section{LITERATURE REVIEW}

\subsection{Concept of Board Composition}

Extant literatures agree that effective boards are makeup of greater proportions of outside directors on board. This agreement on larger proportion of outside directors sitting on the board is highly grounded in agency theory, which 
propagates the separation of ownership and control which may potentially lead to self- interested actions by those in control - managers (Eisenhardt, 1989; Jensen and Meckling, 1976). According to the agency theory, effective boards will be composed of more outside directors. These 'outsiders' are believed to provide superior performance benefits to the firm as a result of their independence from firm management. Some empirical literature support this position as they found positive relationship between outside directors and profitability among firms (Rosenstein \& Wyatt, 1990; Ezzamel \& Watson, 1993; Ramdani \& Van, 2009; Rashid, De-Zoys, Lodh \& Rulkin, 2010; Yasser, Entebang \& Mansor, 2011 and Shah, Butt \& Saeed, 2011)

\subsection{Concept of Board size}

Board size is the number of directors on the board of a firm. There are two schools of thoughts - small and large board size, but there is no agreement on which of them is better. Researchers in the first school of thought are of the opinion that small board size contributes more to the success of a company (Lipton \& Lorsch, 1992; Jensen, 1993; Yermack, 1996). Furthermore, Yermack (1996) argue that a large board is slow in decision making and time wasting and this causes communication problems and affects the firm performance negatively. The second school of thought argues that large board size improves company performance and enables board to gather more information (Pfeffer, 1972; Klein, 1998). However, the number of directors on board seems to have influence on firm performance.

\subsection{Concept of Market Value}

The Market value of an asset or an item is the price that such asset or item of monetary value would fetch in the market place. Market value is also commonly used to refer to the market capitalization of a publicly-traded company, and is obtained by multiplying the number of its outstanding shares by the current share price. Market value is easiest to determine for exchange-traded instruments such as stocks and futures, since their market prices are widely disseminated and easily available, and is a little more challenging to ascertain for overthe-counter instruments like fixed income securities.

A company's market value is a good indication of investors' perceptions of its business prospects. The range of market values in the market place is enormous, ranging from a company with the smallest capital base to the biggest and most successful company operating in the stock market. Market value is determined by the valuations or multiples accorded by investors to companies, such as price-to-sales, price-to-earnings, enterprise value -to- Earnings before Interest Tax and Dividend, and so on. The higher the valuations, the greater the market value of the firm. Market value can fluctuate a great deal over periods of time, and is substantially influenced by the business cycle. Market values plunge during the bear markets that accompany recessions, and rise during the bull markets that are a feature of economic expansion. Market value is also dependent on numerous other factors, such as the manner in which the company is being governed that is the corporate governance put in place in the company's structure; the sector in which the company operates Company's profitability, Debt load and the broad market environment. Market value for a firm may diverge significantly from book value or shareholders' equity. A stock would generally be considered undervalued if its market value is well below book value, which means the stock is trading at a deep discount to book value per share. This does not imply that a stock is overvalued if it is trading at a premium to book value, as this again depends on the sector and the extent of the premium in relation to the stock's peers (Omura 2005).

\subsection{Empirical Studies on Board Composition, Board Size and Firm Value}

Many studies have been conducted by various researchers on the impact of board compositions and board size on firm performance (using different measure of performance) in different part of the world. It can therefore be deduced that there exists a relationship between board composition and market value as well as board size and market value. Some of these studies include studies conducted in both developed and developing economies.

Nguyen and Faff (2007) examined the impact of board size and board diversity on firm value in Australian and found no significant relationship between firm market value and board size.

Raymond, Paul and Jaeyoung (2010) conducted a study to examine the impact of board of director characteristics and financial performance in a Sarbanes Oxley world and found that board size and board composition have positive significant relationship with revenue growth. This implies that the higher the number of directors on board, the higher the market value of the equity of such firm. This finding collaborate with the works of Chiang and Lin (2011) who examined board composition and firm performance of listed companies in Taiwan and the results show that board composition plays an important role in enhancing firm's performance. This result also supports the findings of Khan and Awan (2012) who examined the effect of board composition on firm's performance of Pakistani listed companies. The study found a significant positive relationship between board composition and firm's performance. Again, Tapal and Dogan (2014), examined the impact of board size on financial performance of BIST manufacturing industry and result revealed a positive relationship between the board size and returns on assets and Z-Altman score.

The above findings contradicts the works of Hamidu and Aliyu (2015). Hamidu and Aliyu (2015) examine the relationship between corporate attributes of the board and market value of firms in Nigerian chemical and paints industry. The results of the study revealed that board size has insignificant and negative impact on market value of equity. This implies that higher number of directors on the board decreases the market value of equity. 
Veklenko (2016) examined the impact of board composition on firm's performance in continental Europe. The findings reveals that board composition is positively significant with firm performance but board size has negative and insignificant impact on firms' performance. This finding is similar to the works of Muchemwa and Padia (2016) who examined the impact of board composition, board size on financial performance of Johannesburg stock exchange companies from 2006 to 2012. The result shows that board size and board composition have no significant impact on the performance measures in the South African context. More so, Shanu, Bil and Ombaba (2017) investigated the effect of board size on firm financial performance of listed firms in Nairobi security exchange for the period of ten years 2006 to 2015. The study reported a significant positive effect of board size on firm financial performance. Implying that board size has effect on the market value of a firm.

Pantamee and Ya'u (2018) also examined the effect of board size and board composition on firm performance in Nigerian petroleum marketing industry for a period of ten years from 2004 to 2014. The results reveal that board size is negatively related to return on equity while the relationship between board compositions and returns on equity is positive but insignificant. This finding also supports the works of ElMaude, Bawa and Shamaki (2018). The study investigated the effects of board size, board composition and board meetings on the financial performance of listed companies in Nigeria for the period of ten years from 2006 to 2015. The results of the study shows that board size is negatively related with financial performance but board composition has positive significant relationship with the financial performance of consumer goods companies in Nigeria. The findings support the work of Ahmad and Sallau (2018) who found that board size has a positive but insignificant impact on the market value of listed Deposit Money Banks (DMBs) in Nigeria while board composition has significant impact on market value of listed DMBs in Nigeria.

\subsection{Theoretical Framework}

Different theories have been used by previous researchers to explain the relationships among board composition, board size and market value. However, agency theory is selected to be the most appropriate theory that underpins the current study. This is because agency theory predicts that there is conflict of interest that arises from the separation of ownership from control in organisations (Berle \& Means, 1932; Fama \& Jensen, 1983). From this perspective, the primary function of the board is to monitor the actions of managers - agents - in order to protect the interests of the shareholders - principals (Mizruchi, 1983; Eisenhardt, 1989; Andreasson, 2011). Monitoring by boards of directors may therefore reduce the agency costs inherent in the separation of ownership and control and, in this way, improves firm's performance (Fama, 1980; Zahra \& Pearce, 1989). Agency theory also predicts that the incentives available to directors and boards vary and are therefore important precursor to effective monitoring
(Kyereboah-Coleman \& Biekpe, 2005), and that firm performance will therefore improve if these are aligned with the interests of shareholders (Jensen \& Meckling, 1976; Fama, 1980).

\section{METHODOLOGY}

This study adopts ex-post factor research design, because the study used data extracted from annual reports and accounts of listed industrial goods companies in Nigeria. This was adopted in order to actualize the research objective which is to examine the impact of board composition and board size on market value of industrial goods companies in Nigeria.

The population of the study comprises of all the fifteen (15) companies listed under the Industrial goods sector as at December, 2019. In order to ensure availability of data required by the study ten (10) companies were selected. These companies include; Berger Paints Nig, Beter Glasses Company, Cement of Northern Nigeria, Chemical \& Allied Product, Cutix, First Aluminum Nig, Greif Nig, Lafarge Cement, Meyer Plc, and Premier Paints. Table 3.1 shows the variables used for this study and their measurements

Table 3.1 Variables and their Measurement

\begin{tabular}{|c|c|c|c|}
\hline $\begin{array}{c}\text { Variable } \\
\text { Name }\end{array}$ & $\begin{array}{l}\text { Type of } \\
\text { Variable }\end{array}$ & Measurement & Sources \\
\hline Firm Value & Dependent & $\begin{array}{c}\text { Number of } \\
\text { share divided } \\
\text { by the market } \\
\text { price }\end{array}$ & $\begin{array}{c}\text { Hamidu, \& Aliyu } \\
\text { (2015) }\end{array}$ \\
\hline $\begin{array}{c}\text { Board } \\
\text { Composition }\end{array}$ & Independent & $\begin{array}{l}\text { Number of } \\
\text { Non- } \\
\text { executive } \\
\text { director } \\
\text { divided by } \\
\text { total number } \\
\text { of directors }\end{array}$ & $\begin{array}{c}\text { Muchemwa (2016), } \\
\text { Veklenko (2016), } \\
\text { Ahmadd \& Sallau } \\
\text { (2018) and } \\
\text { Pantamee \& Sallau } \\
\text { (2018) }\end{array}$ \\
\hline Board Size & Independent & $\begin{array}{l}\text { Number of } \\
\text { directors on } \\
\text { board }\end{array}$ & $\begin{array}{c}\text { Tapal \& Dogon } \\
\text { (2014), Hamidu \& } \\
\text { Aliyu (2016), } \\
\text { Muchemwa \& } \\
\text { Padia (2016 and } \\
\text { Ahmad \& Sallau } \\
\text { (2018) }\end{array}$ \\
\hline Firm Size & Control & $\begin{array}{l}\text { Log of total } \\
\text { assets }\end{array}$ & $\begin{array}{c}\text { Tapal \& Dogon } \\
\text { (2014) and Ahmad } \\
\text { \& Sallau (2018) }\end{array}$ \\
\hline
\end{tabular}

Source: Literature Review, 2020

\subsection{Techniques for Data Analysis}

This study uses multiple regression analysis technique, applying ordinary least square, fixed and random effects. The correlation statistical technique was first applied in testing the relationship among the variables of the study. In order to improve the validity of all statistical inferences of the study, robustness tests for multicollinearity and Hausman specification tests were carried out. The main regression model is defined in the following equation:

$$
\begin{aligned}
& \text { SPRit }=\alpha 0+\beta_{1} \text { BCOMit }+\beta_{2} \text { BSIZEit }+\beta_{3} \text { FSizeit }+ \\
& \beta_{4} \text { FageEit }+ \text { Eit }
\end{aligned}
$$


Where; SPR $=$ share price ratio (Market Value)

$\mathrm{BCOM}=$ Board Composition,

BSize = Board Size,

FSIZE $=$ Firm Size,

$\alpha 0=$ Parameters to be estimated.

$\mathrm{B}_{1}-\beta_{4}=$ Partial derivatives or the gradient of the independent variables.

$\varepsilon=$ an error term

$\mathrm{i}=$ Firm

$\mathrm{t}=$ time

\section{RESULTS AND DISCUSSION}

This section presents the results of the analysis conducted on the data collection from the annual report and account of the sample companies under study. The results of the descriptive statistics, correlation, Ordinary Least Square (OLS), Fixed and Random effect are presented in this section.

Table: 4.1 Descriptive Statistics of the Variables

\begin{tabular}{|c|c|c|c|c|}
\hline Variables & Mean & Std.Dev & Min & Max \\
\hline Spr & 16.1286 & 20.8899 & 0.36 & 115 \\
\hline BC & 0.5312 & 0.1871 & 0.1 & 0.8889 \\
\hline BS & 9.4769 & 3.4779 & 5 & 19 \\
\hline FS & 6.6326 & 0.8202 & 5.09 & 8.76 \\
\hline
\end{tabular}

Source: Generated using STATA 12.0

Table 4.1 shows the descriptive statistics of the variables used in the study. The table revealed that share price ratio (spr) has a mean value of 16.1286 , a standard deviation of 20.8899 with a minimum and maximum of 0.36 and 115 respectively, the standard deviation of 20.8899 signified high variation in share price ratio of the companies within the period of under study. Board Composition (bc) has a mean value of 0.5312 , a standard deviation of 0.1871 , with a minimum and maximum of 0.1 and 0.8889 respectively. This indicates that for the period of the study, all the companies under this study have a minimum of $10 \%$ of directors on board as independent directors and a maximum of close to $89 \%$. Board size has mean of 9.4769 , a standard deviation of 3.4779 with a minimum and maximum of 5 and 19 board members respectively. Firm size which is the control variable has mean of 6.5326, a standard deviation of 0.8202 with a minimum and maximum of 5.09 and 8.76 respectively.

Table 4.2 Correlation Matrix of Dependent and Independent Variables

\begin{tabular}{|c|c|c|c|c|c|}
\hline \multicolumn{2}{|c|}{ Correlation } & & & & \\
\hline & SPr & BC & BS & FS & VIF \\
\hline SPr & 1 & & & & \\
\hline BC & -0.1784 & 1 & & & 1.46 \\
\hline
\end{tabular}

\begin{tabular}{|c|c|c|c|c|c|}
\hline BS & 0.2188 & 0.1252 & 1 & & 1.40 \\
\hline FS & 0.5553 & 0.0039 & 0.5347 & 1 & 1.07 \\
\hline
\end{tabular}

Source: Generated using STATA 12.0

The above Correlation Matrix table shows correlation coefficients of the dependent variable (Share Price - Spr) and explanatory variables (Board Composition [bc], Board Size [bs] and Firm Size [fs]). The values of the correlation coefficient range from -1 to 1 . The sign of the correlation coefficient indicates the direction of the relationship (positive or negative), the absolute values of the correlation coefficient indicates the strength, with larger values indicating stronger relationships. The correlation coefficients on the main diagonal are 1.0 , because each variable has a perfect positive linear relationship with itself.

From Table 4.2, it can be seen that $\mathrm{SPr}$ has negative relationship with BC. For instance the relationship between $\mathrm{SPr}$ and $\mathrm{BC}$ is $(\mathrm{r}=-0.1784)$. However, $\mathrm{SPr}$ has positive relationship with $\mathrm{BS}$ and $\mathrm{Fz}$ as shown in the table above $(\mathrm{r}=$ $0.0 .2188)$ and $(r=0.5553)$ respectively. Furthermore, for this study, the VIF and tolerance test was carried out to test for multicollinearity. The VIF and tolerance estimates were found to be much smaller than ten (10), as shown on table 4.2. O'Brien (2007) and Nishida (2019) assert that after estimating a model and computing the VIF, any variable with a VIF value of 10 or more indicates harmful collinearity. From table 4.2 it can be gathered that the VIF of all variables are less than 2. Hence, absence of multicolinearity is confirmed. For this study, following the recommendations of Andrew and Kelvyn, (2014), Bell and Jones (2015) and that of King and Roberts (2015), the random effects model in respect of equation (1) was estimated with robust Generalized Least Squares (GLS) method to control for serial correlation and heteroskedasticity.

Table 4.3 OLS and Fixed Effect

\begin{tabular}{|c|c|c|c|c|c|c|}
\hline & \multicolumn{2}{|c|}{ OLS } & \multicolumn{2}{|c|}{ Fixed Effects } & \multicolumn{2}{|c|}{ Random Effects } \\
\hline Variable & $\begin{array}{c}\text { Coeffi } \\
\text { cient }\end{array}$ & $P>|t|$ & $\begin{array}{l}\text { Coeff } \\
\text { icient }\end{array}$ & $P>|t|$ & $\begin{array}{l}\text { Coeff } \\
\text { icient }\end{array}$ & $\mathrm{P}>\mid \mathrm{z} /$ \\
\hline Constant & $\begin{array}{c}- \\
80.00 \\
99\end{array}$ & 0.226 & $\begin{array}{c}- \\
53.19 \\
3\end{array}$ & 0.132 & $\begin{array}{c}16.40 \\
88\end{array}$ & 0.002 \\
\hline $\mathrm{Bc}$ & $\begin{array}{c}1.456 \\
7\end{array}$ & 0.322 & 3.083 & 0.004 & $\begin{array}{c}3.073 \\
5\end{array}$ & 0.564 \\
\hline Bs & $\begin{array}{c}- \\
0.527 \\
9\end{array}$ & 0.000 & 0.449 & 0.513 & $\begin{array}{c}0.363 \\
3\end{array}$ & 0.003 \\
\hline FS & $\begin{array}{c}15.68 \\
93\end{array}$ & 0.000 & $\begin{array}{c}10.74 \\
2\end{array}$ & 0.045 & $\begin{array}{c}12.10 \\
01\end{array}$ & 0.020 \\
\hline $\begin{array}{c}\mathrm{R} \\
\text { Squared }\end{array}$ & $\begin{array}{c}0.324 \\
9\end{array}$ & & & & & \\
\hline F Value & 20.21 & & & & & \\
\hline Prob F & $\begin{array}{c}0.000 \\
0\end{array}$ & & & 0.029 & & \\
\hline $\begin{array}{c}\mathrm{R} \\
\text { Squared: }\end{array}$ & & & & & & \\
\hline Within & & & & 0.0736 & $\begin{array}{c}0.072 \\
9\end{array}$ & \\
\hline
\end{tabular}




\begin{tabular}{|c|l|l|l|l|c|l|}
\hline Between & & & & 0.3931 & $\begin{array}{c}0.405 \\
6\end{array}$ & \\
\hline Overall & & & & 0.2906 & $\begin{array}{c}0.299 \\
2\end{array}$ & \\
\hline rho & & & & & & \\
\hline & & & & & & \\
\hline $\begin{array}{c}\text { F-value } \\
\text { u_i=o }\end{array}$ & & & & 16.69 & & \\
\hline $\begin{array}{c}\text { Prob > } \\
\text { chi2 }\end{array}$ & & & & & $\begin{array}{c}0.002 \\
3\end{array}$ & \\
\hline
\end{tabular}

Source: Generated using STATA 12.0

Table 4.3 presents the regression results on the relationship between the dependent variable (SPr) and the independent variables of the study (Board composition [bc], Board size $[\mathrm{bs}]$ and Firm Size [fs]). However, in order to make the choice between Fixed Effect (FE) and Random Effect (RE) regression the Hausman specification test was performed. This test was conducted considering the fact that there is a trade-off between the efficiency of the random effect and the consistency of the fixed effect approach. The result of the test revealed that correlation exists because the chi square probability is insignificant (0.7829). Following the results of the Hausman test, the interpretation and discussion of the results for this study were carried out using GLS random effects model. This is due to the fact that the Hausman specification test reveals that RE is more efficient as evident by the $p$-value of 0.7829 which is insignificant i.e. more than 0.05 .

Form table 4.3, the results revealed that board composition has positive and insignificant effect on the share price ratio of the industrial goods companies in Nigeria. The beta coefficient of the variables is 3.0735 with a p-value is 0.564 which is insignificant at $5 \%$ level of significance. In other words, board composition has positive and insignificant effect on the share price ratio of the sample companies. The implication of this finding suggests that the presence of more non-executive directors than executive directors on the board does not influence the share price of companies in the industrial goods sector in Nigeria. Therefore, the first hypothesis which stated that board composition has no significant effect on the share price ratio of listed industrial goods companies should be accepted and this supports the findings of Muchemwa and Padia, (2016). However, it contradicts the findings of Vekleke (2016); and Pantamee and Ya'u (2018) who reported positive and significant effect of board composition on value of firms.

Table 4.3 also revealed that board size has a positively and significant effect on the share price ratio of industrial goods companies in Nigeria. The beta coefficient of the variables is 0.3633 with a p-value of 0.003 which is significant at $5 \%$ level of significance. This indicates that board size has positive significant effect on the share price ratio of industrial goods companies in Nigeria. The implication of this finding is that the bigger the size of the board, the higher the value of the sample companies measure by the share price. This finding is consistent with the findings of Tapal and Dogon (2014) and Shanu Bill and Embaba (2017). However, it contradicts the findings of Pantamee and Ya'u (2018) and El Maude, Bawa and Shamali (2018) who found that board size has insignificant effect on firm value. Based on this finding, hypothesis 2 which stated that board size has no significant effect on the share price ratio of listed industrial goods companies in Nigeria must be rejected.

Similarly, the estimates on table 4.3 also revealed that firm size which is a control variable has positive and significant effect on the share price ratio of listed industrial goods companies in Nigeria. The beta coefficient of the variables is 12.10 with a p-value is 0.020 which is significant at the $5 \%$ level of significance. This indicates that firm size has positive and significant effect on the share price ratio of industrial goods companies in Nigeria. The implication of this finding is that the bigger the size of the firm the higher the share price ratio of the sample firms. The finding is consistent with the findings of Ahmad and Sallau (2018).

\section{CONCLUSION AND RECOMMENDATIONS}

Based on the findings of this study, it is concluded that while board composition has no impact on the market value of industrial goods companies in Nigeria, board size has a positive and significant impact on the market value of industrial goods companies in Nigeria. The study recommends that firms in the industrial goods sector of Nigeria maintain higher number of members on their board to enhance firm value.

\section{REFERENCES}

[1] Adekunle,S.A. \& Aghedo,E.M. (2014). Corporate Governance and Financial Performance of Selected Quoted Companies in Nigeria. European Journal of Business and Management, 6(9).

[2] Ahmed,H.S, \& Sallau,M.M. (2018). Corporate Government and Market Value of Listed Deposit Money Banks in Nigeria. International Accounting and Taxation Research Group. Faculty of Management Sciences, University of Benin, Benin City, Nigeria, $27-42$.

[3] Andreassion,S. (2011). Understanding Corporate Governance Reform in South Africa: Anglo-American.

[4] Andrew, B., \& Kelvyn, J. (2014). Explaining Fixed Effects: Random Effects Modeling of Time-Series Cross-Sectional and Panel Data. Political Science Research and Methods. 1(1), 1 - 21.

[5] Bell, A., \& Jones, K. (2015). Explaining Fixed Effects: Random Effects modelling of Time-Series Cross-Sectional and Panel Data. Political Science Research and Methods, 3, 133 - 153.

[6] Berle,A. \& Means, G. (1932). The Modern Corporation and Private Property. Newyork: Maccmillan.

[7] Chiang,H.T. \& Lin,M.C. (2011). Examining Board Composition and Firm Performance. Intenational Journal of Business and Finance Research , 5(3), 15-27.

[8] Eisenhardt,K. (1989). Agency Theory: An Assessment and Review . The Academy of Management Review, 14, 57-74.

[9] El-Maude,J.G., Bawa, A.B \& Shanaki, A. R. (2018). ffect of Board Size, Board Composition and Board Meetings on Financial Performance of Listed Consumer Goods Companies in Nigeria. International Business Research, 11(6), 1-10.

[10] Fama,A. \& Eugene,F. (1980). Agency Problem and the Theory of the Firm. Journal of Political Economy, 88(2), 288-307.

[11] Fama,E. \& Jensen,M. (1983). Separation of ownership and control . Journal of Law and Economics, 26(3), 301-325. 
[12] Hamidu,I \& Aliyu,M.S. (2015). Corporate Attribute of Board Size and Market Value of Firms in the Nigerian Chemecal and Paints Industry. International Journal of Humanities and Social Science, 5(6), 101-108.

[13] Jensen,M. (1993). The modern industrial revolution, exit and the failure of internal control Mechanism. Journal of Finance, 48(3), 831-880.

[14] Jensen,M. \& Meckling,W. (1976). Theory of the firm: Managerial behavioural, agency costs and ownership structure. Journal of Financial Economics , 3(2), 305-360.

[15] Khan,A. \& Awan,S.H. (2012). Effect of Board Composition on Firm;s Performance: A case of Pakistan listed Companies. Interdisciplanary Journal of Contemporary Reseacrh in Business, 3 (10).

[16] King, G., \& Robert, M. E. (2015). How Robust Standard Errors Expose Methodological Problems They Do Not Fix, and What to Do About It. Political Analysis, 23(2), 159 - 179.

[17] Klein,A. (1998). Firm performance and board committee structure. Journal of Law and Economics, 41, 137-165.

[18] Kyereboah-Coleman,A \& Biekpe,N. (2005). Corporate governance and the peroformance of microfinance institution (MFLs) in Ghana. Working paper, UGBS, Legon.

[19] Lipton,M.\& Lorsch,J. (1992). A modest proposal for improved corporate governance. Business Lawyer, 159-177.

[20] Mizruchi,M. (1983). Who controls Whom? An examination between management and board of directors inlarge American corporation . Academy of Management Review, 8, 426-43.

[21] MousarF. \& Al-Manase. (2012). The Impact of Corporate Governance on the Performance of Jordanian Banks.

[22] Muchemwa, M.R., \& Padia, N,. (2016). Board Composition, Board Size and Financial Performance of Johannesburg Stock Exchange Companies. Southfrican Journal of Economics and Management Science (SAJEMS), 19(2), 497-513.

[23] Nishida, K. (2019). Why Multicollinearity is a problem and How to Detect it in your Regression Models. [Online] Retrieved 27/11/2020 from: https://blog.exploratory.io/whymulticollinearity-is-bad-and-how-to-detect-it-in-your-regressionmodels-e40d782e67e

[24] Nguyen,H. \& Fatt,R. (2007). Impact of Board Size and Board Diversity on Firm Value: Australian Evidence. Corporate Ownership and Control, 4(2), 24-32.

[25] O'Brien, M. (2007). A Caution Regarding Rules of Thumb for Variance Inflation Factors, Quality and Quantity 41(5):673-690

[26] Omura,T. (2005). The relationship between market value and book value for five selected Japanese firms. Thesis.
[27] Pantamee,A. \& Ya"u. (2018). . Effect of Board Size and Board Composition on firm Performance in Nigerian Petroleum Market Industry. Journal of Advance Reseach in Social and Behavioural Science, 10(2), 131-143.

[28] Pfeffer,J. (1972). Size and Composition of Corporate Board of Directors: The Organisation and its Environment. Administrative Science Quarterly, 17, 218-228.

[29] Ragmond,K.V., Poul, M \& Joeyoung, K. (2010). Board of Directors Composition and Financial Performance in a SarbanesOxley World. Academy of Business and Economics Journal, 10(5), 56-74.

[30] Ramdani,D. \& Van,W. (2009). Board Independence, CEO duality and firm performance: A quantile regression analysis for indonesia, Malaysia and Thailand.

[31] Rashid,A., De Zoysa,A., Lodh,S \& Rulkin,K. (2010). Board Composition and firm performance: Evidence from Bangladesh . Australian Accounting Business and Finance Journal, 4(1), 76-95.

[32] Rosenstrein,S \& Wyait,J. (1994). Shareholder weath effects when an officer of one corporation join the board of directors of another. Managerial and Decision Economics, 15, 317-327.

[33] Shah,S.Z.A., Butt,S.A. \& Saeed. (2011). Ownership Structure and Performance of Firms: Empirical evidence from an emerging market . African journal of Business Management, 5(2), 515-523.

[34] Topal, Y. \& Dogon, M,. (2014). Impact of Size on Financial Performance: The Case of BIST Manufacturing . International Journal of Business Management and Economics Research (IJBMER), 5 (4), 74-79.

[35] Veklenico,K. (2015). The Impact of Board Composition on the Firm's Performance in Continental Europe . 7th IBA Bachelor Thesis Conference, july 1st, 2016, Enshede. University of Twente, faculty of Behavioural, Management and Social Sciences, Netherland.

[36] Yasser,Q.R.,Entebang,H. \& Mansor,S.A. (2011). Corporate governance and firm performance in Pakistant: The case of Karachi stock exchange(KSE)-30. Journal of Economics and International Finance, 3(8), 482-491.

[37] Yermack,D. (1996). Higher market valuation of companies with a ssmall board of directors. Journal of Finance Economics, 40, 183211.

[38] Zahra,S.E. \& Peace,J. (1989). Board of directors and corporate fianacial performance: A review and intergrative model. Journal of Management, 15(2), 291-244. 